\title{
The quality of different mono- and dicalcium phosphates estimated on the basis of their crystalline phases, chemical composition, solubility, and biological parameters of broiler chickens
}

\author{
D. Jamroz ${ }^{1,3}$, A. Gajda-Janiak', Z. Wzorek² ${ }^{2}$ Z. Kowalski² and J.K. Kubizna' \\ ${ }^{1}$ Wrockaw University of Environmental and Life Sciences, Department of Animal Nutrition and Feed Quality \\ Chełmońskiego 38C, 51-630 Wrocław, Poland \\ ${ }^{2}$ Cracow University of Technology, Institute of Chemistry and Inorganic Technology \\ Warszawska 24, 31-015 Kraków, Poland
}

KEY WORDS: monocalcium phosphate, dicalcium phosphate, solubility, broilers, biological parameters

Received: 5 July 2012

Revised: 24 May 2013

Accepted: 2 September 2013

${ }^{3}$ Corresponding author: email: dorota.jamroz@up.wroc.pl

\begin{abstract}
The quality of five commercial monocalcium phosphates (MCP) and dicalcium phosphates with natural admixtures of hydrated and dehydrated forms was assessed on the basis of their crystalline phases determined by roentgenographic irradiation, $\mathrm{Ca}$ and $\mathrm{P}$ contents, and solubility in water, $2 \%$ citric acid, $0.4 \% \mathrm{HCl}$, and ammonium citrate solutions. The phosphates were used in diets fed between days 1 and 35 of life to 300 Hubbard Flex male broilers, 6 replications (cages) of 10 chickens per treatment. Performance indices, $\mathrm{Ca}, \mathrm{P}$ and $\mathrm{Mg}$ retention, and the concentration of these elements in blood and bone ash, as well as the physical parameters of femur and tibia bones were measured. The content of $P$ in phosphates varied between $17.7 \%$ and $23 \%$, their solubility in citric acid and $\mathrm{HCl}$ solutions ranged between $89-99 \%$. The roentgenograms indicated that phosphate No. 1 contained pure MCP; No. 2, MCP with admixture of anhydrous dicalcium phosphate (DCP); No. 3, DCP with an admixture of MCP; No. 4, dicalcium phosphate dehydrate (DDCP); No. 5, DDCP with an admixture of DCP. The type of phosphate used in chicken diets did not influence body weight or feed intake. Phosphorous retention, $\mathrm{Ca}$ and $\mathrm{P}$ in serum, and some bone parameters were better in chickens fed the diet containing pure MCP $(P<0.01)$. Lower concentrations of $\mathrm{Ca}$ and $\mathrm{P}$ in bones and worse parameters of bone elasticity were found in chickens fed diets containing DDCP with DCP. In the biological experiment, the overall best results were obtained in chickens fed diets containing pure hydrated monocalcium phosphate.
\end{abstract}

\section{Introduction}

The low availability of native phosphorus from the phytates present in natural feeds, especially in grains (the main components of poultry diets), makes it necessary to add microbial phytases to diets (Leytem et al., 2008). Nonetheless, the supplementation of phosphates, inorganic phosphorus sources, in broiler diets is still indispensable. The biological value of commercial phosphates depends on their natural origin (Fernandes et al., 1999; Gödöy and Chicco, 2001; Weiner et al., 2001; Rama Rao and Rammasubba Reddy, 2003), modifications during 
their production process, chemical purity, and other factors (Ravindran et al., 1995, Wzorek and Kowalski, 1995; De Groote and Huyghebaert, 1997; Jamroz et al., 2001, 2010).

In our earlier extensive studies, 341 different production batches of mono-, di- , tri-, and $\mathrm{Na}$ and $\mathrm{Mg}$ phosphates were analysed. Their chemical composition, crystallography and physical characteristics, as well as solubility in four solvents were determined; the obtained results showed a great variability in their chemical quality (Gajda-Janiak et al., 2005; Jamroz et al., 2010, 2012).

In biological investigations performed on broiler chickens (Jamroz et al., 2012), five hydrated monocalcium phosphates (MCP) with natural admixtures of hydrated and dehydrated forms, differing in crystalline structure and chemical purity were examined. It was concluded that the type of phosphate used had a small effect on both performance indices and some mechanical parameters of bone quality. Significant differences were found, however, in $\mathrm{Ca}$ and $\mathrm{P}$ concentrations and activity of serum alkaline phosphatase. The small differences in the solubility of the MCP used, especially in citric acid, $\mathrm{HCl}$, or ammonium citrate (but not in water) and its crystalline structure led to a significant diversification of $\mathrm{Ca}$ - and $\mathrm{P}$ - contents in blood and bones (Gajda-Janiak et al., 2005; Jamroz et al., 2010, 2012).

Monophosphates are characterized by different solubility, chemical composition, and purity as determined using the roentegenographic technique. Therefore, the objective of the investigations carried in this cycle of studies was to evaluate the quality of mono- and dicalcium phosphates with natural admixtures of hydrated and dehydrated forms based on the response of broiler chickens to rations containing them. Performance, retention of $\mathrm{Ca}, \mathrm{P}, \mathrm{Mg}$, concentration of minerals in blood and in bones, and physical parameters of bone quality were considered as the indices of phosphate quality. The presented studies are a continuation of the investigations cited above.

\section{Material and methods}

In the present study, commercial monocalcium phosphates (MCP) and dicalcium phosphates (DCP) with natural admixtures of hydrated and dehydrated forms were used (Table 1), selected from 341 different phosphates according to the criterion of frequency of similar P and $\mathrm{Ca}$ contents (GajdaJaniak et al., 2005).
Table 1. Characteristics of commercial phosphates on the basis of crystalline phases determination

\begin{tabular}{|c|c|c|c|c|}
\hline No & $\begin{array}{l}\text { Treat- } \\
\text { ments }\end{array}$ & $\begin{array}{l}\text { Kind of phosphates used } \\
\text { in the diets }\end{array}$ & Formula & $\begin{array}{l}\text { Abbrevia- } \\
\text { tion }\end{array}$ \\
\hline 1 & I & $\begin{array}{l}\text { monocalcium phosphate } \\
\text { monohydrate }\end{array}$ & $\mathrm{Ca}\left(\mathrm{H}_{2} \mathrm{PO}_{4}\right)_{2} \times \mathrm{H}_{2} \mathrm{O}$ & MCP \\
\hline 2 & II & $\begin{array}{l}\text { monocalcium phosphate } \\
\text { monohydrate with admix- } \\
\text { ture of anhydrous dicalci- } \\
\text { um phosphate }\end{array}$ & $\begin{array}{l}\mathrm{Ca}\left(\mathrm{H}_{2} \mathrm{PO}_{4}\right)_{2} \times \mathrm{H}_{2} \mathrm{O} \\
\mathrm{CaHPO}_{4}\end{array}$ & $\begin{array}{l}\mathrm{MCP}+ \\
\mathrm{DCP}\end{array}$ \\
\hline 3 & III & $\begin{array}{l}\text { anhydrous dicalcium } \\
\text { phosphate with admixture } \\
\text { of monocalcium phos- } \\
\text { phate monohydrate }\end{array}$ & $\begin{array}{l}\mathrm{CaHPO}+ \\
\mathrm{Ca}\left(\mathrm{H}_{2} \mathrm{PO}_{4}\right)_{2} \times \mathrm{H}_{2} \mathrm{O}\end{array}$ & $\begin{array}{l}\mathrm{DCP}+ \\
\mathrm{MCP}\end{array}$ \\
\hline 4 & IV & $\begin{array}{l}\text { dicalcium phosphate } \\
\text { dehydrate }\end{array}$ & $\mathrm{CaHPO}_{4} \times 2 \mathrm{H}_{2} \mathrm{O}$ & $\mathrm{DDCP}$ \\
\hline 5 & V & $\begin{array}{l}\text { dicalcium phosphate } \\
\text { dihydrate with admixture } \\
\text { of anhydrous dicalcium } \\
\text { phosphate }\end{array}$ & $\begin{array}{l}\mathrm{CaHPO}_{4} \times 2 \mathrm{H}_{2} \mathrm{O} \\
+\mathrm{CaHPO}_{4}\end{array}$ & $\begin{array}{l}\mathrm{DDCP}+ \\
\mathrm{DCP}\end{array}$ \\
\hline
\end{tabular}

MCP - monocalcium phosphates; DCP - dicalcium phosphate; DDCP _ dicalcium phosphate dehydrate

\section{Physical and chemical analytical methods of estimation of phosphate characteristics}

The crystalline phases of phosphates were evaluated using X-ray irradiation, diffraction, and interference of waves on the crystalline walls using a Philips X Pert diffractometer combined with a graphite monochromator, $\mathrm{PW} 1752 / 00$ with a $\mathrm{Cu} \mathrm{K} \alpha$ radiation at range of $2^{\circ}-10^{\circ}-60^{\circ}$. The roentgenographic images allow identification of the crystalline phases of the main phosphates and natural admixtures (Table 1, Figures 1-5).

The chemical composition of feed phosphates was assayed according to the method described by the European Chemical Industry Council (CEFIC), Brussels, Inorganic Feed Phosphates Quality. Total phosphorus content, expressed as $\mathrm{P}_{2} \mathrm{O}_{5}$ (Regulation 2003/2003/EC, method 3.2) was determined by a gravimetric method using quinolone phosphomolybdate (dissolving the samples in a mixture of hydrochloric acid $(\mathrm{HCl} ; 1.19$ $\left.\mathrm{M} \cdot 1^{-1}\right)$ and nitric acid $\left(\mathrm{HNO}_{3} ; 1.4 \mathrm{M} \cdot 1^{-1}\right) 1: 3 \mathrm{v}: \mathrm{v}$ at the boiling point). Calcium in phosphates was determined by complexometry after dissolution in nitric acid using disodium versenate (EDTA; $2.02 \mathrm{M} \cdot \mathrm{1}^{-1}$ ) and the indicators, fluorexone with thymolphtalein. The solubility of phosphorus from inorganic phosphates was tested according to the methods recommended by the European Chemical Industry Council (Environmental Protection Agency, 2003). The following features were examined: solubility in water and solubility in $2 \%$ citric acid (Regulation 2003/2003/EC, method 3.1.3; temp. $20^{\circ} \mathrm{C}$, 35-40 min, P content was determined by a gravimetric method using quinolone phosphomolybdate); solubility in $0.4 \% \mathrm{HCl}$; solubility in ammonium citrate $\mathrm{pH} 7$ (Regulation 2003/2003/EC, method 3.1.5; temp. $65^{\circ} \mathrm{C}$, 


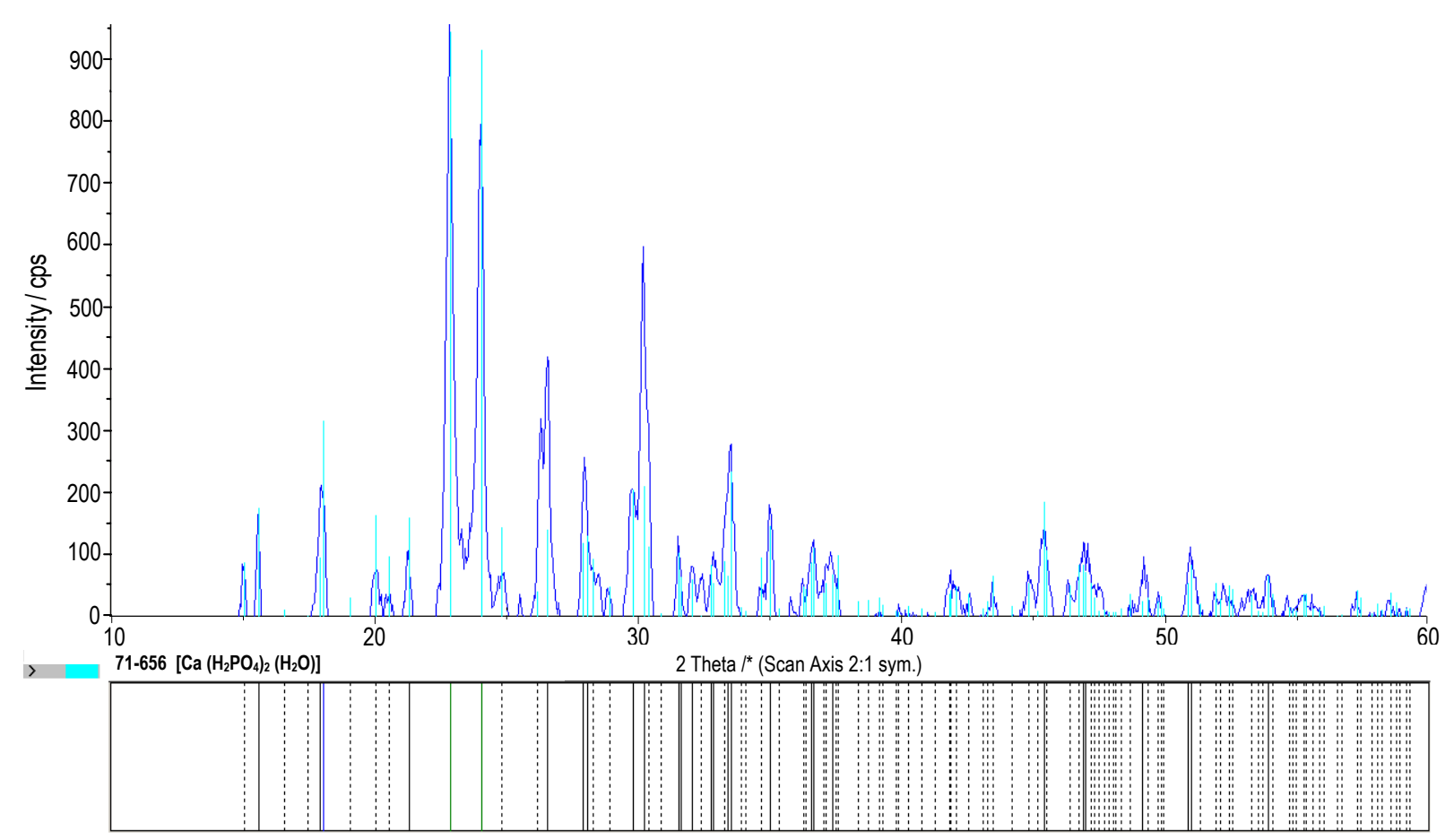

Figure 1. Roentgenogram of phosphate No. 1 with main phase of MCP

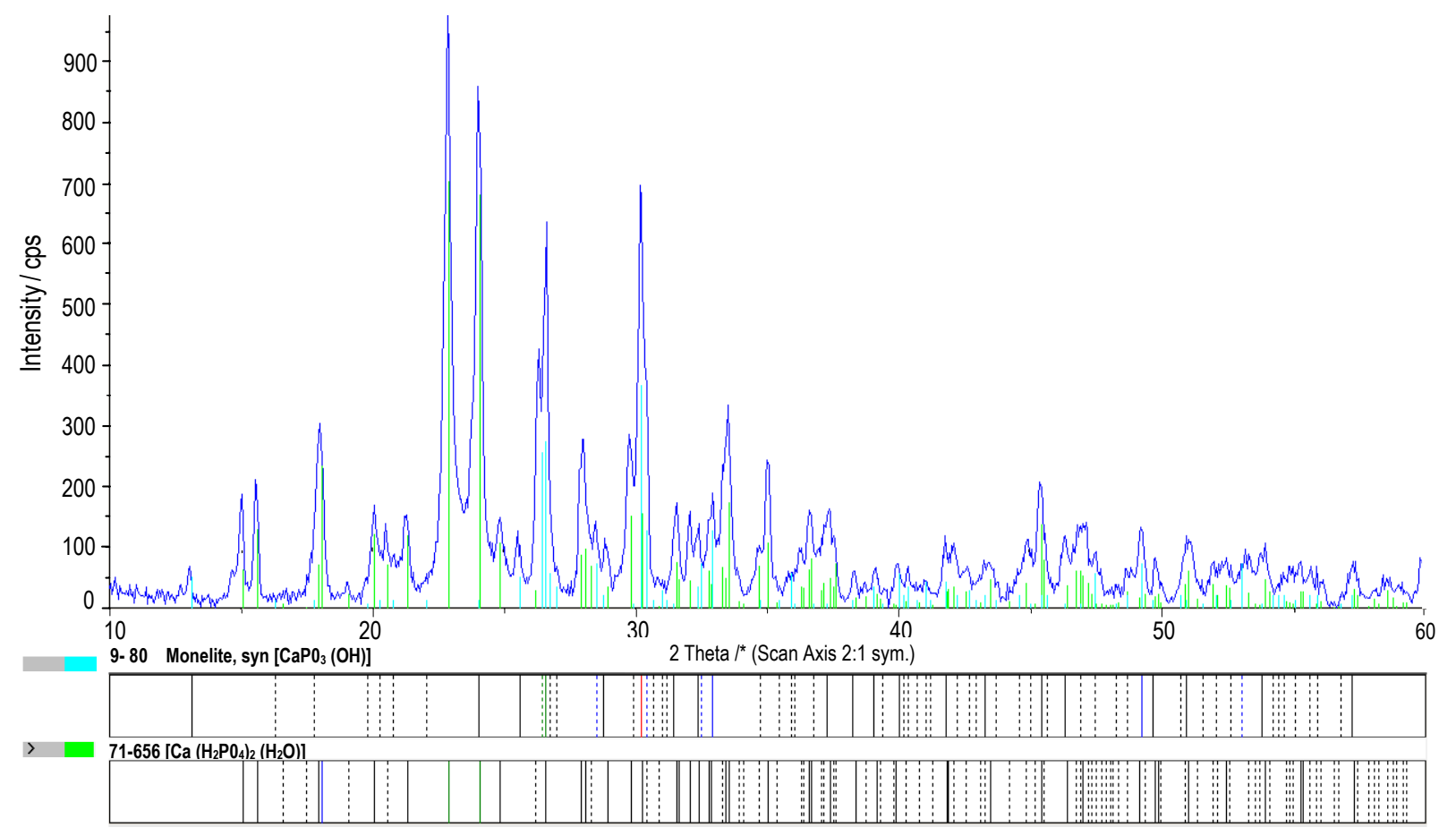

Figure 2. Roentgenogram of phosphate No. 2 with main phase of MCP with admixture of DCP 


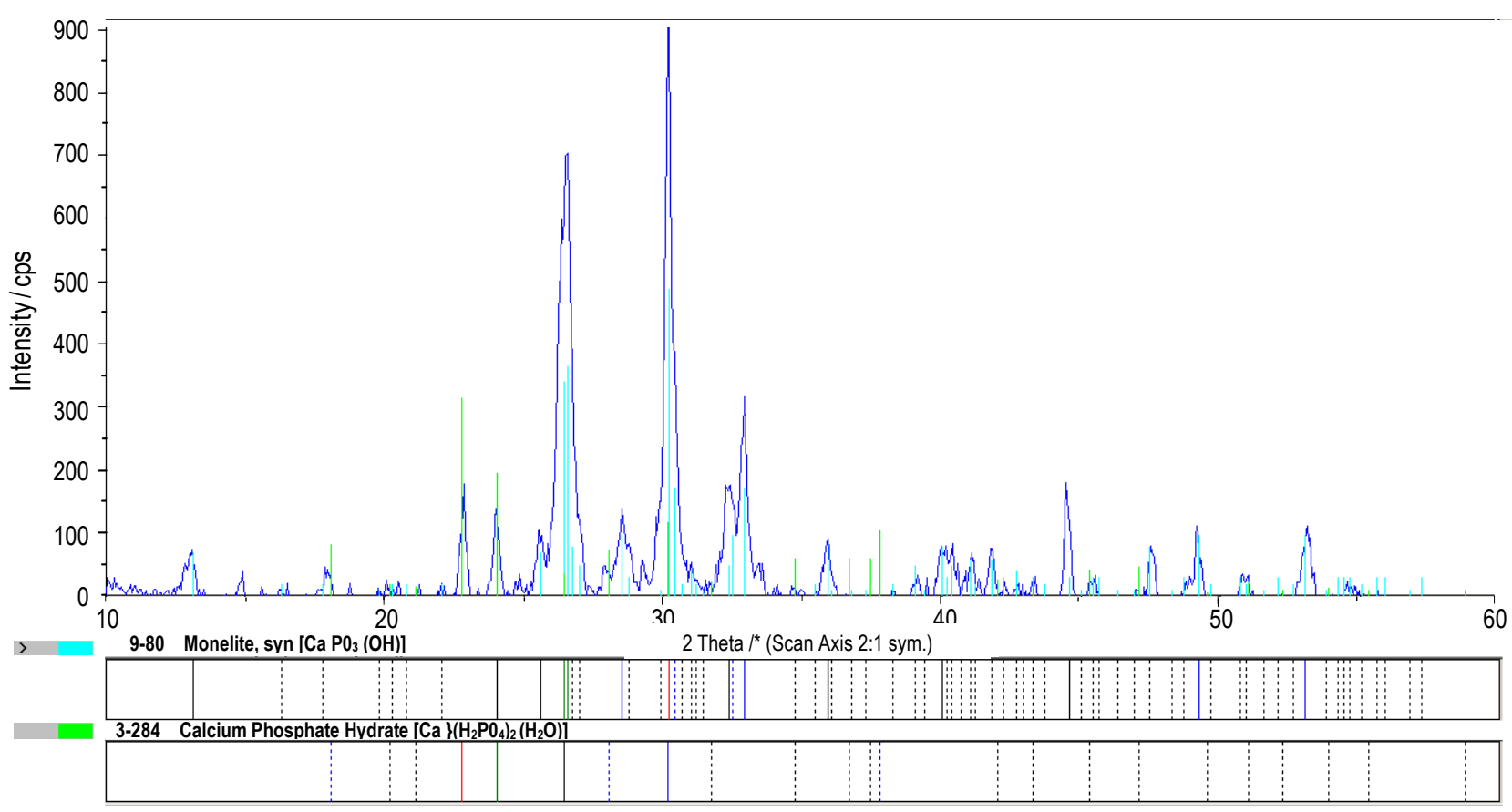

Figure 3. Roentgenogram of phosphate No. 3 with main phase of DCP with admixture of MCP

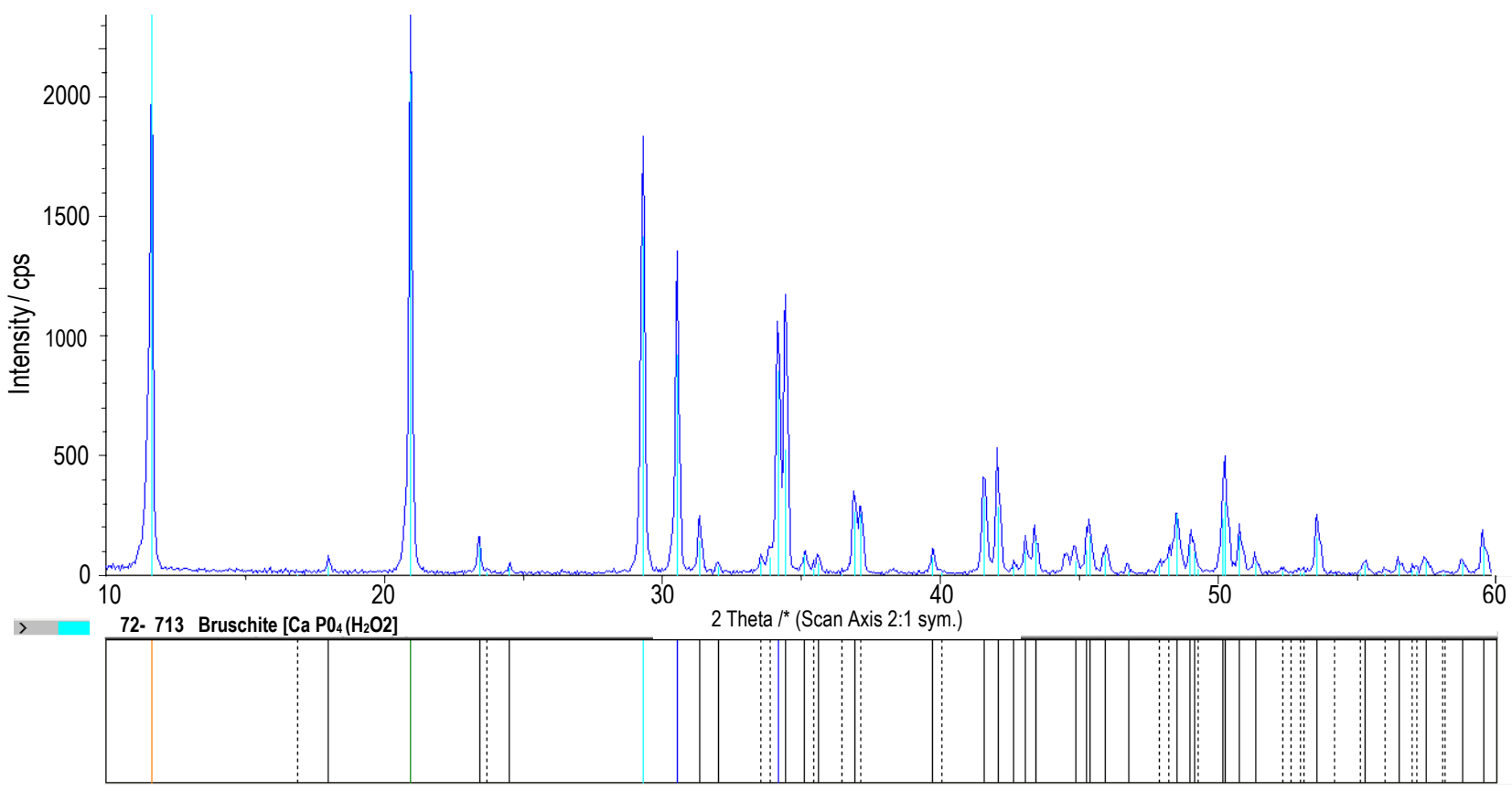

Figure 4. Roentgenogram of phosphate No. 4 with main phase of DDCP 


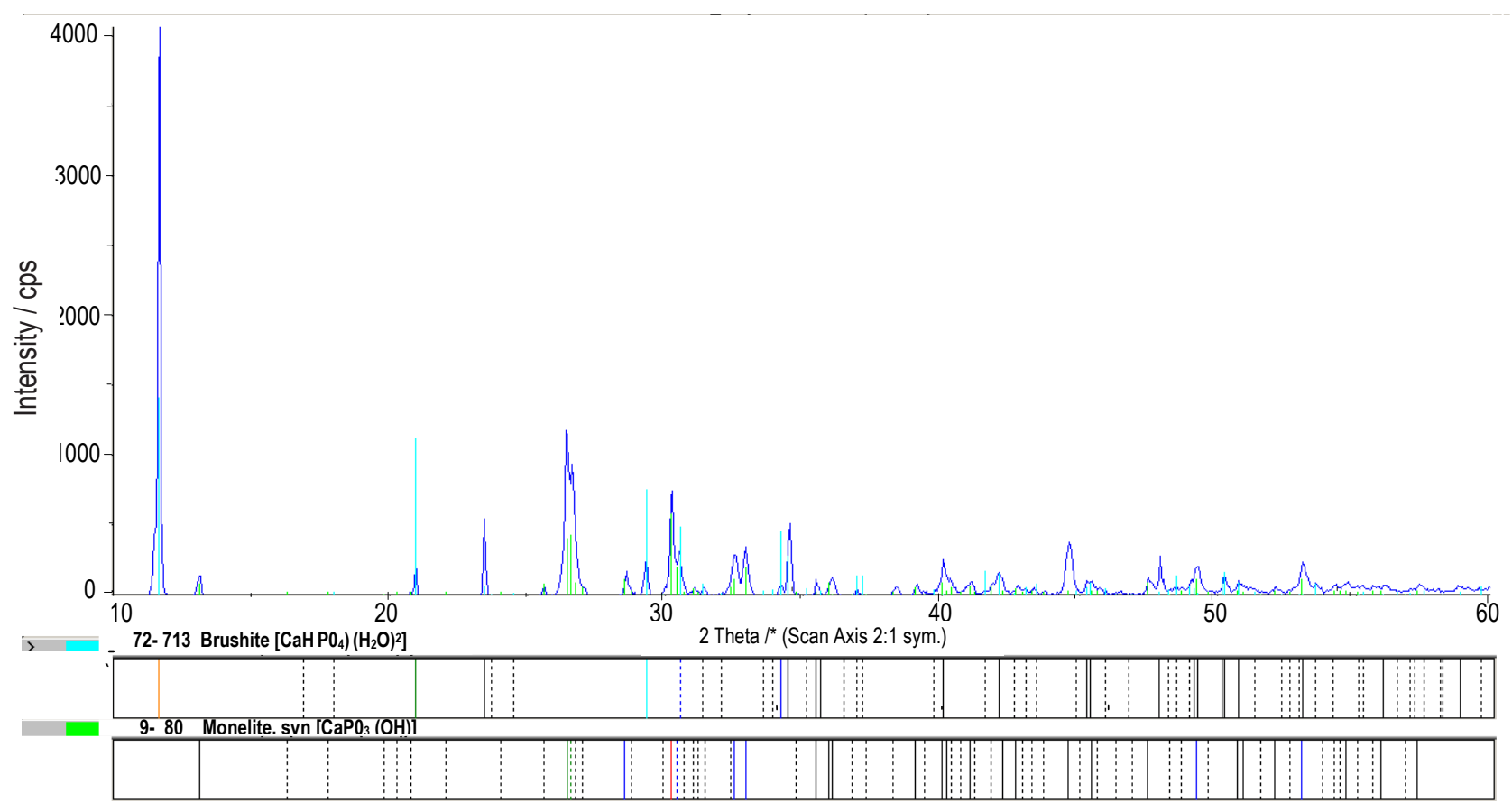

Figure 5. Roentgenogram of phosphate No. 5 with main phase of DDCP with admixture of DCP

alkaline citrate from diammonium citrate $\mathrm{pH}$ 9.4-9.7; 30 min +60 min, $P$ content was determined by a gravimetric method using quinoline phosphomolybdate).

\section{Birds and diets}

All procedures were approved by the Local Animal Care and Use Committee in Wroclaw.

Three hundred one-day-old Hubbard Flex male chicks, with an average body weight of $47.3 \pm 1.0 \mathrm{~g}$, were randomly assigned to five dietary treatments (Table 1). The chickens were reared in battery cages and each treatment had six replicates (cages) with 10 birds per cage. The environmental temperature was reduced from $32^{\circ} \mathrm{C}$ to $21^{\circ} \mathrm{C}$, the lighting programme was $24 \mathrm{~h}$ light per day in the first week, then during 8 to 35 days, $16 \mathrm{~h}$ light per day. The birds had free access to drinking water served via a nipple system and to feeders containing feed mixtures in mash form.

On days $1-10$ the birds were fed the prestarter mix, on days 11-12, the starter, and on days $22-35$, the grower mixes differing in the content of mono- and dicalcium phosphates. The birds of all treatments were fed isoproteinous and isoenergetic diets based on similar amounts of wheat, maize and soyabean meal (Table 2). The crude protein content amounted to about $222 \mathrm{~g} \cdot \mathrm{kg}^{-1}$ in the prestarter and starter, and to $202 \mathrm{~g} \cdot \mathrm{kg}^{-1}$ in the grower diets. The contents of $\mathrm{Ca}$ and $\mathrm{P}$ were equalized. In the diet offered in treatment I, pure MCP was used; in treatment II, MCP with an admixture of DCP; in treatment III, DCP + MCP; in IV, pure dicalcium
Table 2. Composition of experimental diets, $\mathrm{g} \cdot \mathrm{kg}^{-1}$

\begin{tabular}{lccc}
\hline Specification & Prestarter $^{1}$ & Starter $^{1}$ & Grower $^{2}$ \\
& $1-10$ days & $11-20$ days & $21-35$ days \\
\hline Wheat & $214-226$ & $217-227$ & $250-269$ \\
Maize & 353 & 353 & 353 \\
Soyabean meal & $336-345$ & $315-337$ & $270-297$ \\
Soya oil & $32-37$ & $39-41$ & $50-54$ \\
Vitamin-mineral premix & $10.0^{1}$ & $10.0^{1}$ & $10.0^{2}$ \\
DL-methionine $98 \%$ & $3.0-3.1$ & $2.9-3.0$ & $2.8-2.9$ \\
L-lysine 98\% & $0.7-1.0$ & $0.5-1.0$ & $1.0-1.9$ \\
NaCl & 2.8 & 2.8 & 2.9 \\
Phosphate & $15.9-21.0$ & $13.8-18.4$ & $12.0-16.0$ \\
Limestone & $13.6-20.7$ & $15.4-21.7$ & $14.3-19.8$ \\
ME, MJ·kg-1 & 12.2 & 12.4 & 12.8 \\
Crude protein & 224.4 & 220.7 & 201.9 \\
Crude fat & 62.2 & 69.8 & 79.8 \\
Crude fibre & 33.7 & 33.4 & 32.9 \\
Met + Cys & 9.31 & 9.10 & 8.9 \\
Lysine & 12.52 & 12.01 & 11.5 \\
Ca & 10.5 & 10.5 & 9.5 \\
P total & 7.8 & 7.3 & 6.7 \\
P available & 5.0 & 4.5 & 4.0 \\
Mg & 1.8 & 1.7 & 1.6 \\
\hline
\end{tabular}

1 provided per $\mathrm{kg}$ of diet, IU: vit. A 12000 , vit. $\mathrm{D}_{3} 3000$; mg: vit. E 35, vit. $K_{3} 2.5$, vit. $B_{1} 3$, vit. $B_{2} 7$, vit. $B_{6} 5$, vit. $B_{12} 0.02$, biotin 0.15 , nicotinic acid 40 , calcium panthotenate 14 , folic acid 1.5 , choline $600, \mathrm{Mn}$ 70, Fe 70, Cu 15, Zn 60, Se 0.2, Co 0.3, J 1, coccidiostat salinomycin (Sacox 120) 60; ${ }^{2}$ provided per kg of diet; IU: vit. A 10000 , vit. $D_{3}$ 2000; mg: vit. $E 30$, vit. $K_{3} 1.5$, vit. $B_{1} 2$, vit. $B_{2} 5$, vit. $B_{6} 3$, vit. $B_{12}$ 0.015 , biotin 0.15 , nicotinic acid 25 , calcium panthotenate 10 , folic acid 0.8, choline 500, Mn 60, Fe 50, Cu 15, Zn 50, Se 0.2, Co 0.2, J 0.7; ${ }^{3}$ calculated according to Smulikowska and Rutkowski (2005) 
phosphate dehydrate (DDCP); and in treatment V, DDCP with an admixture of DCP was used. The vitamin-mineral premixes used in this study were free of antibiotic growth promoters or alternative substances and contained a coccidiostat.

\section{Measurements and sample collection}

The body weight of chickens of each replicate was determined on days 1, 21 and 35 . Feed intake was recorded for the periods of 1-21 and 22-35 days of life, as well as for the whole experimental period. The feeds were given twice a day in quantities enabling the consumption of the entire portion in a short time. Mortality and the causes of death were recorded. The retention of minerals was determined between days 31-35 of life. Feed intake was registered, excrements were collected twice a day and stored at $+4^{\circ} \mathrm{C}$, then lyophilized for chemical assays. The averages for replication were calculated. On day 35 post-hatch, all chickens were individually weighed, then sixteen birds from each treatment ( 2 or 3 birds per replication) were randomly selected on the basis of average weight within a replication.

The birds were killed by cervical dislocation, then both legs were cut off. The muscles were removed, the femurs and tibias were cleaned and stored for assessment of quality parameters (32 bones per treatment). For mechanical measurements, 16 left femurs and 16 left tibias were used. The same number of the right bones was designated for chemical analysis using the procedures described by Kim et al. (2004) and Jamroz et al. (2004, 2007). Such mechanical parameters as breaking strength and deflection were determined in fresh bones using the INSTRON 5544 (USA) device. Bone deflection was measured by a standard method, in which the force (F) was applied at a distance of $\mathrm{L}=13 \mathrm{~mm}$ to the shaft of a bone supported on both epiphyses. The advance value of the head during estimation of breaking force on an INSTRON apparatus was $0.8 \mathrm{~mm} \cdot \mathrm{min}^{-1}$ for bones of 35-day-old birds. Force (F) was increased up to the moment that the bone broke. The elasticity coefficient, $\mathrm{F} \cdot \mathrm{h}^{-1}$, was also calculated. On the basis of mechanical measurements, the maximum loading force Fn (force at break point), maximum bone deflection hn (deflection at break point), maximum bone deflection $\mathrm{Un}=\mathrm{hn} \cdot \mathrm{l}^{-1}$, and breaking work (work needed to break the bone) were calculated. The measurement techniques were presented in detail by Jamroz et al. (2004). Sixteen right bones were defatted in ether extract for $24 \mathrm{~h}$ according to the Soxhlet method and dried at $45^{\circ} \mathrm{C}$. Crude ash and $\mathrm{Ca}$, $\mathrm{P}$ and $\mathrm{Mg}$ content were determined in each of them.

\section{Chemical analyses}

Feed components and complete diets were chemically analysed according to standard AOAC (2005) methods: the nitrogen content by the Kjeldahl method using a Kjeltec 2300 apparatus produced by Foss Tecator (Sweden); crude protein by multiplication of the $\mathrm{N}$ content by 6.25 ; crude fat by ether extraction; crude fibre by the HennebergStohmann method using a Fibertec Tecator apparatus (Sweden); phosphorus content in experimental diets and bones was analysed after mineralization with nitric acid $\left(\mathrm{HNO}_{3}\right)$ and perchloric acid $\left(\mathrm{HClO}_{4}\right)$ by the ammonium vanadomolybdate method using a Spekol 11 (Carl Zeiss, Jena) spectrophotometer at a wave length of $470 \mathrm{~nm}$; calcium and magnesium in diets and bones were determined by atomic absorption spectrophotometry using an AA 240 FS type apparatus (Candela).

Serum $\mathrm{Ca}$ was determined photometrically with a CPC test; P by UV, and Mg using LCF tests (EMAPOL, Poland). Alkaline phosphatase (E.C. 3.1.3.1)wasdeterminedbyaBiosystemsmethodusing di-sodium4-nitrophenylphosphate(CAS4264-83-9). Nutrients and amino acids were chemically determined in the separate components. On the basis of the obtained data, the diets were calculated using a simplex optimization, and then, the nutritive value in complete feed mixtures was controlled again and the averages for each diet were calculated. The energy value of diets was calculated on the basis of determined nutrients and according to the formula published in the European Tables of Energy Values of Feeds for Poultry (1989) and amounted to $12.2 / 12.8 \mathrm{MJ} \cdot \mathrm{kg}^{-1}$.

\section{Statistical analysis}

All data were statistically evaluated by onefactorial ANOVA using StatSoft Statistica ${ }^{\circledR}$ software (2005). The differences for all parameters were tested according to the following statistical model:

$$
Y_{i j}=\mu+a_{i}+e_{i j}
$$

where: $Y_{i j}-$ means the variance associated with parameter $a, \mu$ - the overall mean, $a_{i}$ - the treatment effect (kind of phosphate), $e_{i j}$ - the error.

The replication measurements or individual data for blood and bone parameters were treated as the experimental units and differences between treatment means were analysed for significance $(P<0.01$ or $p<0.05)$ using Tukey's test. The data are presented as averages and are accompanied by $\pm \mathrm{SD}$. 


\section{Results}

The examined phosphates were characterized by large differences in solubility in water $(1.1 \%-79.7 \%)$. When citric acid and $\mathrm{HCl}$ solutions were used to simulate the conditions in the animal stomach, the solubility of phosphates was similar and varied between 89\%-99\% (Table 3). Phosphates Nos. 1 and 2 had a similar $\mathrm{Ca}$ and $\mathrm{P}$ contents and solubility parameters. The roentgenograms of phosphates Nos. 1 and 2 show only relatively similar crystalline phase images resulting from different presences of MCP and DCP (Figures 1 and 2), however, the presence of the main phase of DDCP (Figures 4 and 5) clearly differentiates the crystalline image of phosphates Nos. 4 and 5.

Table 3. Content of P-total, $\mathrm{Ca}$ and solubility of phosphates used in experiment

\begin{tabular}{|c|c|c|c|c|c|c|c|}
\hline \multirow{2}{*}{\multicolumn{2}{|c|}{$\begin{array}{l}\text { Treatments - } \\
\text { phosphates with } \\
\text { admixture }\end{array}$}} & \multirow{2}{*}{$\begin{array}{l}\text { P-total } \\
\text { in } \mathrm{P}_{2} \mathrm{O}_{5}, \%\end{array}$} & \multirow{2}{*}{$\begin{array}{l}\mathrm{Ca} \\
\%\end{array}$} & \multicolumn{4}{|c|}{$\begin{array}{l}\text { Phosphate solubility } \\
\text { expressed as } \mathrm{P}_{2} \mathrm{O}_{5}, \%\end{array}$} \\
\hline & & & & \multirow{2}{*}{$\begin{array}{r}\mathrm{H}_{2} \mathrm{O} \\
79.7\end{array}$} & \multirow{2}{*}{$\begin{array}{l}2 \% \text { citric } \\
\text { acid }\end{array}$} & \multirow{2}{*}{$\begin{array}{l}0.4 \% \\
\mathrm{HCl} \\
96.2\end{array}$} & \multirow{2}{*}{$\begin{array}{l}\begin{array}{l}\text { ammo } \\
\text { nium } \\
\text { citrate }\end{array} \\
93.2\end{array}$} \\
\hline I & MCP & 23.0 & 17.0 & & & & \\
\hline$\|$ & MCP with DCP & 22.9 & 17.2 & 78.1 & 97.6 & 99.6 & 92.7 \\
\hline III & $\mathrm{DCP}$ with $\mathrm{MCP}$ & 20.2 & 22.3 & 18.7 & 18.7 & 89.8 & 71.3 \\
\hline IV & $\mathrm{DDCP}$ & 17.7 & 22.8 & 1.2 & 97.8 & 99.5 & 61.1 \\
\hline V & DDCP with DCP & ( ) & 25.7 & 1.1 & 97.1 & 98.6 & 33.6 \\
\hline
\end{tabular}

MCP, DCP, DDCP - see Table 1

The average body weight of chickens in the treatments on days 21 and 35 post hatch did not differ significantly. The average daily feed intake calculated for the period of days 1-35 amounted to 77-79 g; FCR, about $1.55 \mathrm{~kg}$ per kg BW (Table 4). In all of the treatments, bird mortality was low (single cases only). The considerable differences in the solubility of the analysed phosphates did not correlate with performance parameters, except for $\mathrm{P}$ retention, which was significantly higher $(P<0.01$; $61.3 \%$ ) in the group fed the diet containing pure MCP.

Table 4. Body weight and feed intake of chickens (means)

\begin{tabular}{|c|c|c|c|c|c|c|}
\hline \multirow[b]{2}{*}{ Item } & \multicolumn{5}{|c|}{ Treatments } & \multirow[b]{2}{*}{ SEM } \\
\hline & MCP & $\begin{array}{l}\text { MCP } \\
\text { with } \\
\text { DCP }\end{array}$ & $\begin{array}{l}\mathrm{DCP} \\
\text { with } \mathrm{MCP}\end{array}$ & $\mathrm{DDCP}$ & $\begin{array}{l}\text { DDCP } \\
\text { with } \\
\text { DCP }\end{array}$ & \\
\hline \multicolumn{7}{|l|}{ Body weight, g } \\
\hline on day 21 & 721 & 736 & 735 & 737 & 734 & 1.95 \\
\hline on day 35 & 1995 & 1987 & 1968 & 1992 & 2005 & 5.40 \\
\hline \multicolumn{7}{|c|}{$\begin{array}{l}\text { Average feed intake in } \\
\text { the period }\end{array}$} \\
\hline $\begin{array}{l}\text { 1-35. day of life, } \\
\mathrm{g} \cdot \text { head } \cdot \text { day }^{-1}\end{array}$ & 77.6 & 79.7 & 79.0 & 79.0 & 77.2 & 0.606 \\
\hline $\mathrm{FCR}, \mathrm{kg} \cdot \mathrm{kg}^{-1} \mathrm{BW}$ & 1.538 & 91.587 & 71.573 & 1.570 & 01.525 & 0.772 \\
\hline
\end{tabular}

All differences between treatments were insignificant; MCP, DCP, DDCP - see Table 1
Table 5. Balance of minerals in 35 days old chickens (means)

\begin{tabular}{|c|c|c|c|c|c|c|}
\hline \multirow[b]{2}{*}{ Specification } & \multicolumn{5}{|c|}{ Treatments } & \multirow{2}{*}{ - SEM } \\
\hline & MCP & $\begin{array}{l}\text { MCP } \\
\text { with } \\
\text { DCP }\end{array}$ & $\begin{array}{l}\text { DCP } \\
\text { with } \\
\text { MCP }\end{array}$ & $\mathrm{DDCP}$ & $\begin{array}{l}\text { DDCP } \\
\text { with } \\
\text { DCP }\end{array}$ & \\
\hline$P$ - intake, $\mathrm{g} \cdot \mathrm{kg}^{-1}$ & $1.82^{\mathrm{A}}$ & $1.65^{\mathrm{B}}$ & $1.62^{B}$ & $1.50^{B}$ & $1.62^{B}$ & 0.017 \\
\hline P - excreted, g.day ${ }^{-1}$ & 0.70 & 0.79 & 0.75 & 0.75 & 0.77 & 0.015 \\
\hline $\begin{array}{l}P \text { - retained, } \\
\% \text { of intake }\end{array}$ & $61.3^{\mathrm{A}}$ & $51.9^{\mathrm{Ba}}$ & $53.9^{\mathrm{Bb}}$ & $50.2^{\mathrm{Ba}}$ & $52.2^{\mathrm{Bb}}$ & 0.507 \\
\hline $\mathrm{Ca}$ - intake, g day $^{-1}$ & $1.81^{\mathrm{a}}$ & $1.80^{\mathrm{a}}$ & $1.74^{a b}$ & $1.66^{b}$ & $1.74^{\mathrm{ab}}$ & 0.018 \\
\hline $\mathrm{Ca}$ - excreted, $\mathrm{g} \cdot \mathrm{day}^{-1}$ & $0.70^{b}$ & $0.80^{\mathrm{Aa}}$ & $0.73^{b c}$ & $0.68^{b}$ & $0.61^{\mathrm{Bd}}$ & 0.012 \\
\hline $\begin{array}{l}\text { Ca retained, } \\
\% \text { of intake }\end{array}$ & $61.3^{A}$ & $55.4^{\mathrm{B}}$ & $58.2^{\mathrm{AB}}$ & $59.4^{\mathrm{AB}}$ & $65.1^{\mathrm{C}}$ & 0.552 \\
\hline $\mathrm{Mg}$ - intake, $g \cdot$ day $^{-1}$ & 0.37 & 0.37 & 0.38 & 0.36 & 0.37 & 0.004 \\
\hline $\mathrm{Mg}$ - excreted, g.day ${ }^{-1}$ & $0.25^{\mathrm{ab}}$ & $0.27^{a}$ & $0.27^{\mathrm{a}}$ & $0.24^{b}$ & $0.25^{\mathrm{ab}}$ & 0.004 \\
\hline $\begin{array}{l}\text { Mg retained, } \\
\% \text { of intake }\end{array}$ & $33.6^{b}$ & $27.4^{a}$ & $28.2^{\mathrm{c}}$ & $32.7^{\mathrm{bc}}$ & $33.4^{b}$ & 0.711 \\
\hline
\end{tabular}

a,b,A,B means in the rows with different letters are different at:

a,b $p<0.05$; A,B $P<0.01$; MCP, DCP, DDCP - see Table 1

In other treatments these values varied between $50.2 \%$ and $53.9 \%$ (Table 5). Ca-retention varied between $55.4 \%-65.1 \%$. In birds fed diets containing pure MCP or DDCP with a DCP admixture, the retention of $\mathrm{Ca}$ amounted to $61 \%$ and $65 \%$, respectively $(P<0.01)$. The best $\mathrm{Mg}$ retention was found in birds fed diets containing pure MCP, DDCP + DCP, or DDCP.

The serum parameters reflect the variability caused by the feed phosphates used (Table 6). Significantly higher $\mathrm{Ca}$ and $\mathrm{P}$ concentrations were found in chickens fed the diet containing pure MCP $(P<0.01)$. The $\mathrm{Mg}$ concentration was higher in chickens fed the diets with pure MCP and DCP with an admixture of MCP $(P<0.01$ and $p<0.05)$. The kind of phosphate used did not cause any significant differences in serum alkaline phosphatase activity. Some mechanical parameters, i.e. maximum force needed to break the femur and tibia, were similar in all treatments (Table 7). A significantly lower elasticity of femur bones was found in chickens fed the diet containing $\mathrm{DDCP}+\mathrm{DCP}(P<0.01)$. Tibia elasticity was similar in all treatments. The young module was significantly lower only in the femur $(p<0.05)$ of birds fed the diet with DDCP+DCP. In the tibia, similar values of this parameter were found. The kind of phosphate used significantly $(p<0.05)$ affected the crude ash content only in the tibia (Table 8 ). The highest amount of ash was found in the tibia of chickens fed the diet with pure MCP $(p<0.05)$. 
Table 6. Ca, P, Mg concentration and alkaline phosphatase activity in blood serum in 35 days old chickens (means)

\begin{tabular}{lllllll}
\hline \multirow{2}{*}{ Item } & Treatments & & & & \\
\cline { 2 - 5 } & MCP & $\begin{array}{l}\text { MCP } \\
\text { with DCP }\end{array}$ & $\begin{array}{l}\text { DCP } \\
\text { with MCP }\end{array}$ & DDCP & $\begin{array}{l}\text { DDCP } \\
\text { with DCP }\end{array}$ & SEM \\
\hline $\mathrm{Ca}, \mathrm{mmol}^{-1}$ & $2.59^{\mathrm{A}}$ & $2.14^{\mathrm{B}}$ & $2.18^{\mathrm{B}}$ & $2.22^{\mathrm{B}}$ & $2.22^{\mathrm{B}}$ & 0.021 \\
$\mathrm{P}, \mathrm{mmol}^{-1}$ & $3.56^{\mathrm{Aa}}$ & $3.13^{\mathrm{b}}$ & $3.27^{\mathrm{ab}}$ & $3.05^{\mathrm{B}}$ & $3.01^{\mathrm{B}}$ & 0.026 \\
${\mathrm{Mg}, \mathrm{mmol}^{-1}}^{\text {Alkaline phosphatase }} \begin{array}{l}1.10^{\mathrm{ab}} \\
\text { activity, } \mathrm{U} \cdot \mathrm{l}^{-1}\end{array}$ & $1.06^{\mathrm{b}}$ & $1.17^{\mathrm{Aa}}$ & $1.04^{\mathrm{B}}$ & $1.08^{\mathrm{ab}}$ & 0.006 \\
\hline
\end{tabular}

a,b,A,B means in the rows with different letters are different at: a,b $p<0.05 ;$;, $\mathrm{B} P<0.01$; MCP, DCP, DDCP - see Table 1

Table 7. Physical parameters of femur and tibia bones in 35 day old chickens (means)

\begin{tabular}{|c|c|c|c|c|c|c|}
\hline \multirow[b]{2}{*}{ Specification } & \multicolumn{5}{|l|}{ Treatments } & \multirow[b]{2}{*}{ SEM } \\
\hline & MCP & $\begin{array}{l}\text { MCP } \\
\text { with DCP }\end{array}$ & $\begin{array}{l}\text { DCP } \\
\text { with MCP }\end{array}$ & DDCP & $\begin{array}{l}\text { DDCP } \\
\text { with DCP }\end{array}$ & \\
\hline \multicolumn{7}{|l|}{ Femur } \\
\hline maximum breaking force, $\mathrm{N}$ & 207.1 & 200.1 & 204.7 & 204.9 & 203.3 & 1.259 \\
\hline elasticity, $N \cdot \mathrm{m}^{-1}$ & $1.54 \times 10^{5 \mathrm{~A}}$ & $1.50 \times 10^{5 \mathrm{~A}}$ & $1.30 \times 10^{5 A B}$ & $1.28 \times 10^{5 \mathrm{AB}}$ & $1.11 \times 10^{5 B}$ & $0.182 \times 10^{5}$ \\
\hline young module, $\mathrm{N} \cdot \mathrm{m}^{-2}$ & $6.57 \times 10^{9 a}$ & $6.43 \times 10^{5 a b}$ & $5.74 \times 10^{9 a b}$ & $5.74 \times 10^{9 a b}$ & $4.53 \times 10^{9 b}$ & $0.715 \times 10^{8}$ \\
\hline \multicolumn{7}{|l|}{ Tibia } \\
\hline maximum breaking force, $\mathrm{N}$ & 388.9 & 353.3 & 362.3 & 24.1 & 382.3 & 2.256 \\
\hline elasticity, $\mathrm{N} \cdot \mathrm{m}^{-1}$ & $2.29 \times 10^{5}$ & $2.34 \times 10^{5}$ & $2.15 \times 10^{5}$ & $2.16 \times 10^{5}$ & $2.53 \times 10^{5}$ & $0.337 \times 10^{5}$ \\
\hline young module, $\mathrm{N} \cdot \mathrm{m}^{-2}$ & $1.22 \times 10^{10}$ & $1.19 \times 10^{10}$ & $1.06 \times 10^{10}$ & $1.31 \times 10^{10}$ & $1.15 \times 10^{10}$ & $0.800 \times 10^{5}$ \\
\hline
\end{tabular}

Table 8. Content of crude ash, $\mathrm{Ca}, \mathrm{P}$ and $\mathrm{Mg}$ in bone ash in 35 days old chickens (means)

\begin{tabular}{|c|c|c|c|c|c|c|}
\hline \multirow[b]{2}{*}{ Specification } & \multicolumn{5}{|c|}{ Treatments } & \multirow[b]{2}{*}{ SEM } \\
\hline & $\mathrm{MCP}$ & $\begin{array}{l}\text { MCP } \\
\text { with DCP }\end{array}$ & $\begin{array}{l}\text { DCP } \\
\text { with MCP }\end{array}$ & $\mathrm{DDCP}$ & $\begin{array}{l}\text { DDCP } \\
\text { with DCP }\end{array}$ & \\
\hline \multicolumn{7}{|l|}{ Femur } \\
\hline $\begin{array}{l}\text { crude ash, } \% \\
\text { content in ash, } \mathrm{g} \cdot \mathrm{kg}^{-1}\end{array}$ & 45.5 & 45.2 & 43.2 & 45.2 & 42.6 & 0.360 \\
\hline $\mathrm{Ca}$ & $224.1^{\mathrm{A}}$ & $219.6^{A}$ & $218.8^{A}$ & $208.4^{\mathrm{B}}$ & $200.5^{\mathrm{C}}$ & 0.742 \\
\hline$P$ & $170.1^{A}$ & $172.7^{\mathrm{ab}}$ & $171.3^{\mathrm{a}}$ & $172.5^{\mathrm{a}}$ & $176.1^{\mathrm{Bb}}$ & 0.472 \\
\hline $\mathrm{Mg}$ & $6.4^{\mathrm{B}}$ & $5.5^{\mathrm{C}}$ & $5.7^{\mathrm{A}}$ & $6.2^{\mathrm{Ba}}$ & $6.7^{\mathrm{Bb}}$ & 0.054 \\
\hline \multicolumn{7}{|l|}{ Tibia } \\
\hline $\begin{array}{l}\text { crude ash, } \% \\
\text { content in ash, } \mathrm{g} \cdot \mathrm{kg}^{-1}\end{array}$ & $45.8^{\mathrm{Aa}}$ & $42.0^{b}$ & $43.0^{\mathrm{ab}}$ & $41.0^{\mathrm{B}}$ & $41.8^{\mathrm{b}}$ & 0.389 \\
\hline $\mathrm{Ca}$ & $217.6^{A}$ & $215.1^{A}$ & $215.5^{\mathrm{A}}$ & $206.8^{B C}$ & $196.4^{\mathrm{D}}$ & 0.563 \\
\hline$P$ & 170.5 & 172.9 & 173.0 & 170.9 & 172.9 & 0.443 \\
\hline $\mathrm{Mg}$ & $6.2^{\mathrm{Ab}}$ & $5.5^{\mathrm{B}}$ & $5.4^{\mathrm{B}}$ & $6.1^{\mathrm{Ab}}$ & $6.6^{\mathrm{Aa}}$ & 0.049 \\
\hline
\end{tabular}

a,b,A,B,C,D means in the rows with different letters are different at: ${ }^{a, b} p<0.05 ;$; $, B, C, D, P<0.01$; MCP, DCP, DDCP - see Table 1

The $\mathrm{Ca}$ concentration in crude ash was higher in bones from birds fed diets with MCP or phosphates containing MCP $(P<0.01)$. Differences in phosphorus concentrations in bone ash among treatments were found to be significant in the femur (the highest for DDCP + DCP) and in significant in the tibia. The highest $\mathrm{Mg}$ contents in femur and tibia ash were found in birds fed MCP, DCP, and $\mathrm{DDCP}+\mathrm{DCP}(P<0.01$ and $p<0.01$, respectively $)$. Unclear convergence was observed between physical parameters and the chemical composition of bones.

\section{Discussion}

Despite much research on the development of the best methods for assaying the biological value of phosphates and on the degree of phosphorus utilization from different chemical bonds, the problems related to phosphorus utilization in animal organisms have still not been well elucidated (Anselme, 2003; Rodehutscord and Dieckmann, 2005; Narcy et al., 2009; Rodehutscord, 2009). According to some opinions, determination of phosphate solubility is sufficient for estimating their usefulness for animals (Sullivan et al., 1992; Ravindran et al., 1995; 
De Groote and Huyghebaert, 1997). The results of our studies show that no direct relation between phosphate solubility and chemical composition and chicken performance can be found. A more distinct response of chickens to the kind of phosphate administered was seen in blood $\mathrm{Ca}, \mathrm{P}$ and $\mathrm{Mg}$ concentrations and the content of these elements in bone ash (Jamroz et al., 2012). Similar results were also obtained in the current investigations.

Research carried out by Rath et al. (2000), Jamroz et al. (2001, 2004, 2007), Shapiro and Heaney (2003) and Hemme et al. (2004) shows that the $\mathrm{Ca}$ and $\mathrm{P}$ contents in bones and bone mineralization indices may be good parameters reflecting phosphate quality. In the present study, the best chemical composition (albeit, not for all mineral elements) was found in the bones of chickens fed the diet containing pure hydrated monocalcium phosphate. These results were accompanied by the highest serum $\mathrm{Ca}, \mathrm{P}$ and $\mathrm{Mg}$ concentrations. The physical parameters of bones, strength and elasticity estimated for the femur and tibia, do not give unambiguous information about the dependence between phosphate characteristics and quality and bone mechanical indices. The best mechanical parameters of the femur were found in chickens fed diets with MCP. For the tibia, all of the differences among treatments were insignificant. Significant differences among treatments in $\mathrm{Ca}, \mathrm{P}$ and $\mathrm{Mg}$ contents in bone ash were recorded. The highest values of $\mathrm{Ca}$ and $\mathrm{Mg}$ were determined in chickens fed diets containing MCP, but the P level in ash measured in the same treatment was the lowest.

\section{Conclusions}

On the basis of results reported by Jamroz et al. (2012) as well as in the present study, it can be concluded that the quality of phosphates influences the performance of broilers and their mechanical bone parameters to a small degree. The higher $\mathrm{P}$ retention found in the present study, however, and higher concentration of $\mathrm{Ca}, \mathrm{P}$ and $\mathrm{Mg}$ in blood and in bone ash in chickens fed diets containing pure monocalcium phosphates (MCP) in comparison with birds fed dicalcium phosphate dehydrate (DDCP) with dicalcium phosphate (DCP) admixture, point to the superior value of MCP in comparison with DDCP with a DCP admixture. The roentgenographic analysis of phosphate crystalline characteristics could be good supplemental information, mainly for the producers of phosphates, but the usefulness of this kind of quality estimation of phosphates in biological evaluation on broilers was not confirmed.

\section{References}

Anselme P., 2003. Phosphorus in poultry nutrition. Kraftfutter - Feedmagazine $3,1-4$

AOAC, 2005. Association of Official Analytical Chemists, Official Methods of Analysis. $17^{\text {th }}$ Edition, Arlington, VA

CEFIC, 2006. European Chemical Industry Council, Inorganic Feed Phosphates Quality, Brussels http://feedphosphates.org/ guide/test_method.html

De Groote G., Huyghebaert G., 1997. The bio-availability of phosphorus from feed phosphates for broilers as influenced by bio-assay method, dietary Ca-level and feed form. Anim. Feed Sci. Tech. 69, 329-340

Environmental Protection Agency, 2003. National Pollutant Discharge Elimination System Permit Regulation and Effluent Limitation Guidelines Standards for Concentrated Animal Feeding Operations; Final rule. Federal Register, February, 12,68, 71757274

European Tables of Energy Values for Poultry Feedstuffs, 1989. $3^{\text {rd }}$ Edition. WPSA, Wageningen (The Netherlands), pp. 11-28

Fernandes J.I.M., Lima F.R., Mendonca C.X. Jr., Mabe I., Albuquerque R., Leal P.M., 1999. Relative bioavailability of phosphorus in feed and agricultural phosphates for poultry. Poultry Sci. 78, 1729-1736

Gajda-Janiak A., Jamroz D., Wzorek Z., 2005. Physico-chemical properties of phosphates applied in animal feeding. Pol. J. Chem. Tech. 7, 20-23

Gödöy S., Chicco C.F., 2001. Relative bio-availability of phosphorus from Venezuelan raw rock phosphates for poultry. Anim. Feed Sci. Tech. 94, 103-113

Hemme A., Spark M., Wolf P., Paschertz H., Kamphues J., 2004. Effects of different phosphorus sources in the diet on bone composition and stability (breaking strength) in broilers. J. Anim. Physiol. Anim. Nutr. 89, 129-133

Jamroz D., Gajda-Janiak A., Wzorek Z., Kowalski Z., 2010. Physicochemical evaluation of feed phosphates as a criterion of their classification. Krmiva 52, 299-315

Jamroz D., Gajda-Janiak A., Wzorek Z., Kowalski Z., Kubizna J., 2012. Chemical and biological characteristics of different hydrated monocalcium phosphates for broiler chickens. Ann. Anim. Sci. 12, 187-200

Jamroz D., Wertelecki T., Żyłka R., 2007. The retention of mineral substances, quality and chemical composition of bones in chickens fed diets containing different calcium and phosphorus level. Electr. J. Polish Agr. Univ. Ser. Animal Husbandry. http://www. ejpau.media.pl/volume10/issue3/animal/art-04.html

Jamroz D., Wertelecki T., Żyłka R., Bodarski R., Gajda-Janiak A., 2004. Mechanical, chemical and spectroscopic analysis of mineralisation rate as methods of bones quality determination in broiler chickens. Electr. J. Polish Agr. Univ. 7.2. Ser. Animal Husbandry. http://www.ejpau.media.pl/volume7/ issue2/animal/art-04.html

Jamroz D., Wertelecki T., Żyłka R., Schleicher A., 2001. Retention of calcium and phosphorus from different phosphates and their influence on bone mineralization in chickens. Chem. Agric. Czech Republ. 2, 365-371

Kim W.K., Donaldson L.M., Herrera P., Woodward C.L., Kubena L.F., Nisbet D.J., Ricke S.C., 2004. Effects of different bone preparation methods (fresh, dry and fat-free dry) on bone parameters and correlation between bone breaking strength and bone parameters. Poultry Sci. 83, 1663-1666 
Leytem A.B., Willing B.P., Thacker P.A., 2008. Phytate utilization and phosphorus excretion by broiler chickens fed diets containing cereal grains varying in phytate and phytase content. Anim. Feed Sci. Tech. 146, 160-168

Narcy A., Letourneau-Montminy M.P., Magnin M., Lescoat P., Jondreville C., Sauvant D., Nys Y., 2009. Phosphorus utilization in broilers. In: Proceedings of $17^{\text {th }}$ European Symposium on Poultry Nutrition. Edinburgh (UK), pp. 14-20

Rama Rao S.V., Ramasubba Reddy V., 2003. Relative bio-availability and utilization of phosphatic fertilisers as sources of phosphorus in broilers and layers. Brit. Poultry Sci. 44, 96-103

Rath N.C., Huff G.R., Huff W.E., Balog J.M., 2000. Factors regulating bone maturity and strength in poultry. Poultry Sci. 79, 10241032

Ravindran V., Kornegay E.T., Potter L.M., Ogunabameru B.O., Welten M.K., Wilson J.H., Potchanakorn M., 1995. An evaluation of various response criteria in assessing biological availability of phosphorus for broilers. Poultry Sci. 74, 1820-1830

Rodehutscord M., 2009. Approaches and challenges for evaluating phosphorus sources for poultry. In: Proceedings of $17^{\text {th }} \mathrm{Eu}-$ ropean Symposium on Poultry Nutrition. Edinburgh (UK), pp. 2-6
Rodehutscord M., Dieckmann A., 2005. Comparative studies with three week-old chickens, turkey, ducks and quails on the response criteria in assessing biological availability of phosphorus for broilers. Poultry Sci. 84, 1252-1260

Shapiro R., Heaney R.P., 2003. Co-dependence of calcium and phosphorus for growth and bone development under conditions of varying deficiency. Bone $32,532-540$

Smulikowska S., Rutkowski A. (Editors), 2005. Recommended Allowances and Nutritive Value of Feedstuffs. Poultry Feeding Standards (in Polish). $4^{\text {th }}$ Edition. Institute of Animal Physiology and Nutrition, PAS, Jabłonna (Poland)

Statistica, 2005. Software, ver. 7.1.

Sullivan T.W., Douglas J.H., Gonzales N.J., Bond Jr P.L., 1992. Correlation of biological value of feed phosphates with their solubility in water, dilute hydrogen chloride, dilute citric acid and ammonium citrate. Poultry Sci. 71, 2065-2074

Weiner M.L., Salminen W.F., Larson P.R., Barter R.A., Kranetz J.L., Simon G.S., 2001. Toxical review of inorganic phosphates. Food Chem. Toxicol. 39, 759-786

Wzorek Z., Kowalski Z., 1995. Thermal method of feed phosphate production using phosphorus salts (in Polish). Przem. Chem. $74,463-466$ 